\title{
Studies on Experimental Porphyria
}

\section{Report I. Increased Synthesis of $\delta$-Aminolevulinic Acid in Allylisopropylacetamide-induced Porphyria Rat*}

\author{
By \\ Takashi Miyakoshi** and Goro Kikuchi \\ From the Department of Biochemistry, Tohoku University \\ School of Medicine, Sendai
}

(Received for publication, December 24, 1962)

Acute intermittent porphyria, the most common type of porphyria, shows an increased excretion of porphyrin as well as porphobilinogen (PBG) and $\delta$ aminolevulinic acid ( $\delta$-ALA) in urine, being accompanied with distinctive clinical syndromes. Similar conditions can be induced experimentally in animals by overadministration of some sleeping drugs and the drug-induced porphyria has been the subject of many investigations ${ }^{1-9}$ ) which aimed to clarify the biochemical bases of acute porphyria.

In porphyria cases, in spite of the fact that large amounts of porphyrins and related intermediaries are excreted in urine, the level of liver catalase as well as hemoglobin concentration does not fall. This would indicate that the activity of porphyrin biosynthesis must be increased in some way in porphyria cases. In fact, Sano $^{8)}$ obtained an evidence showing that the step of $\delta$-ALA synthesis from glycine was significantly stimulated in porphyria animals induced by lead poisoning, and suggested that this step might be the site of "first disorder" in porphyria. Also it was reported by Merchante $e t a l .{ }^{4)}$ that the rate of conversion of $\mathrm{PBG}$ to porphyrin by liver homogenates from porphyria rat induced by allylisopropylacetylcarbamide (Sedormid) was almost same as those observed for

宮腰 孝, 菊地吾郎

* This work was aided in part by a research grant for the Applied Science from the Ministry of Education of Japan. A part of this work was taken from the thesis of T. Miyakoshi, submitted to the Tohoku University for the degree of Doctor of Medical Science.

** Present address: Department of Neuropsychiatry, Tohoku University School of Medicine.

Following abbrebiations were used in this paper. AIA, allylisopropylacetamide; $\delta$. ALA, $\delta$-aminolevulinic acid; PBG, porphobilinogen; ATP, adenosine triphosphate; ADP, adenosine diphosphate; NAD, nicotinamide-adenine dinucloetide; NADH, reduced nicotinamide-adenine dinucleotide; NADP, nicotinamide-adenine dinucleotide phosphate; CoA, coenzyme A: EDTA, ethylenediamine tetraacetate. 
normal rat, suggesting that the increased excretion of PBG in urine of porphyria rat might be due not to the block of PBG metabolism but to the "overproduction" of PBG in liver. Recently Urata and Granick" reported that in a chemical porphyria of guinea pig induced by feeding 3,5-dicarbethoxy-1,4-dihydrocollidine, the $\delta$-ALA synthetase activity of liver mitochondria was markedly elevated, although it remains to be elucidated whether the observed increase in activity would reflect or not the actual increase in $\delta$-ALA synthetase content in mitochondria.

This paper is a report of our study on a chemical porphyria in rat induced by allylisopropylacetamide. The data obtained strongly support the idea that the increased synthesis of $\delta$-ALA in liver mitochondria may be a principal feature of porphyria.

\section{MATERIALS AND METHODS}

Reagents: Allylisopropylacetamide was a generous gift of Hoffmann-La Roshe \& Co. Basele, and likewise were $\delta$-aminolevulinic acid, of Daiichi Chemical Co., Tokyo; aminoacetone phthalimide, of Dr. Gumpei Urata; and $\delta$-ALA-5-C ${ }^{14}$, of Dr. David Shemin; for these the authors are indebted. Succinate-1,4-C ${ }^{14}$ and Citrate-1,5-C ${ }^{14}$ were purchased from Daiichi Chemical Co., Tokyo. NADH, NADP, ATP and ADP were purchased from Sigma Chemical Co., U.S.A. Coenzyme A was the product of Pabst Laboratories, U.S.A. Other reagents were obtained commercially.

Induction of porphyria: AIA was fed, mixed with cheese and lard, to white rats weighing from $130 \mathrm{~g}$. to $160 \mathrm{~g}$. at a daily dose of approximately $100 \mathrm{mg}$. Those rats excreting marked porphyrins (from 100 to $300 \mu \mathrm{g}$. per day) in urine were used as AIA-administered rat (AIA rat).

Preparation of rat liver mitochondria: Rat was exsanguinated by carotid amputation, and liver was removed promptly. Liver mitochondria were prepared according to the method of Schneider and Hogeboom ${ }^{10)}$ with a slight modification: liver was homogenized in Potter-Elvehjem apparatus with 9 volumes of $0.25 M$ sucrose solution containing $10^{-4} M$ EDTA, followed by centirfugation at $550 \times g$ for 10 minutes and the resulting supernatant fraction was centrifuged at $7,000 \times g$ for 10 minutes; the precipitates obtained were washed once with the same sucrose solution, then suspended in the same sucrose solution measuring half or four times the volume of the initial liver according to the purpose of experiments. Protein contents of mitochondrial preparations were determined by the Microkjeldahl method.

Syntheses of $\delta-A L A$ and aminoacetone and analyses of reaction products: Reactions were run at $38^{\circ} \mathrm{C}$ for 60 minutes in Warburg's manometric flasks. In aerobic experiments, substrates were tipped in immediately after the flask was immersed in a water bath. Anaerobiosis was furnished by flashing the flask 
with nitrogen gas for 15 minutes. Incubation was terminated by the addition of an equal volume of $0.3 M$ trichloroacetic acid to the reaction mixture. Aminoketones produced were measured by the modified method of Granick ${ }^{11)}$ : to $1.0 \mathrm{ml}$. of trichloroacetic acid extract, $1.0 \mathrm{ml}$. of $1 M$ acetate buffer $(\mathrm{pH} 4.6)$ and $0.05 \mathrm{ml}$. of $2.5 \mathrm{~N} \mathrm{NaOH}$ were added, and the mixture was heated in a boiling water bath for 10 minutes. After cooling, $2 \mathrm{ml}$. of modified Ehrlich's reagent were added and the mixture was left at room temperature for 15 minutes, then spectrum was taken by Hitachi Recording Spectrophotometer, ESP 2. Extinction coefficient of $\delta$-ALA was assumed as $\varepsilon_{m} . y^{553}=53$, and that of aminoacetone, $\varepsilon_{m .11^{552}}=58$. Yields of aminoketones were calculated on the basis of difference in absorption between test and control runs, in the latter no substrate being added. Results of a typical experiment are shown in Fig. 1. Radioactive samples were measured by a windowless gas-flow counter from Nihon Musen Irigaku-kenkyusho, Tokyo. When $\mathrm{C}^{14} \mathrm{O}_{2}$ was the marked product, $100 \mu$ moles of $\mathrm{Na}_{2} \mathrm{CO}_{3}$ were added as the

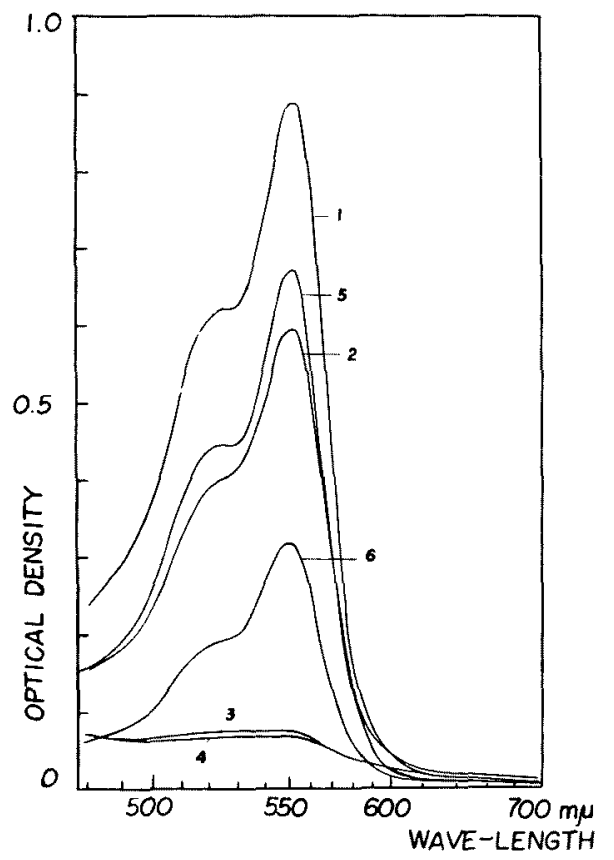

Fig. 1. Absorption spectra of reaction products and authentic aminoketones.

Data were taken from experiments presented in Table I (AIA rat, aerobic). Spectra were measured after the samples were treated following the modified assay method of Granick.

1. $a$-Ketoglutarate-glycine system.

2. Pyruvate-glycine system.

3. Incubation $O$ time.

4. Incubated without substrates.

5. Authentic sample of $\delta$-ALA, final $1.26 \times 10^{-5} M$.

6. Authentic sample of aminoacetone, final $5.5 \times 10^{-6} M$. 
carrier and counted as $\mathrm{BaCO}_{3}$.

\section{RESULTS}

\section{1) $\delta$-ALA and Aminoacetone Syntheses by Liver Mitochondria}

Syntheses of $\delta$-ALA and aminoacetone by rat liver mitochondrial preparations from normal and AIA administered rats were examined (Table I). Liver mitochondria from normal rat produced only a trace amount of aminoketone when $\alpha$-ketoglutarate and glycine were the substrates, while a large amount of aminoketone was synthesized by the mitochondria from AIA rat. The aminoketone can be synthesized anaerobically as well as aerobically in these systems. The aminoketone produced in $\alpha$-ketoglutarate-glycine system was identified as $\delta$-ALA and shown to contain practically no aminoacetone by the following experiments. Glycine-2-C $\mathrm{C}^{14}$ and $\alpha$-ketoglutarate were incubated with liver mitochondria from AIA rat and the products, after being added with suitable amounts of non-labeled authentic $\delta$-ALA and aminoacetone as carriers, were

TABLE I. Syntheses of $\delta$-Aminolevulinic Acid and Aminoacetone

\begin{tabular}{|c|c|c|c|}
\hline & & $\begin{array}{c}\delta \text {-ALA formed } \\
(\mathrm{m} \mu \mathrm{moles} / \mathrm{mg} \text {, prot. } / \mathrm{hr})\end{array}$ & $\begin{array}{l}\text { Aminoacetone formed } \\
\text { (m } \mu \mathrm{moles} / \mathrm{mg} . \text { prot. } / \mathrm{hr} .)\end{array}$ \\
\hline Normal Rat & $\begin{array}{l}\text { aerobic } \\
\text { anaerobic }\end{array}$ & $\begin{array}{l}0.33 \\
0.21\end{array}$ & $\begin{array}{l}5.56 \\
0.19\end{array}$ \\
\hline AIA Ret & $\begin{array}{l}\text { aerobic } \\
\text { anaerobic }\end{array}$ & $\begin{array}{l}7.30 \\
5.64\end{array}$ & $\begin{array}{l}4.20 \\
0.49\end{array}$ \\
\hline
\end{tabular}

8.ALA synthesis systems contained in final volume of $2 \mathrm{ml}$.: phosphate buffer $(\mathrm{pH}$ 7.0) $100 \mu$ moles, $\mathrm{MgCl}_{2} 5 \mu$ moles, EDTA $25 \mu$ moles, glycine $100 \mu$ moles, $\alpha$-ketoglutarate 10 $\mu$ moles, and $1.0 \mathrm{ml}$. of mitochondrial suspension (mitochondria from normal rat, $33.8 \mathrm{mg}$. protein; mitochondria from AIA rat, $34.7 \mathrm{mg}$. protein). Aminoacetone synthesis system were same as above except that $\alpha$-ketoglutarate was replaced by $200 \mu$ moles of pyruvate and $200 \mu$ moles of glycine were used and $5 \mu$ moles of ATP were added. Reactions were run for 60 minutes at $38^{\circ} \mathrm{C}$ in Warburg's flasks.

converted to pyrrole compounds by the condensation with acetylacetone in the same way as described in the previous section. The pyrrole compounds were extracted in ethylacetate, concentrated by evaporation under reduced pressure and below $40^{\circ} \mathrm{C}$, then subjected to ascending zone paper chromatography on Toyo filter paper No. 50, using the solvent system of n-butanol-1.5 M ammonia $(1: 1 \text { vol. })^{12)}$ at $20^{\circ} \mathrm{C}$ for 12 hours. After the chromatography, the paper was cut into strips and from each strip the compounds were eluted with water. The location of the pyrrole compounds was identified by use of modified Ehrlich's reagent. Radioactivity was found to be associated with the one component which showed the same $\mathrm{Rf}(0.2)$ as that of the authentic pyrrole compound from $\delta$-ALA, and practically none in the other component (Rf 0.9) which 
corresponded to the authentic pyrrole compound from aminoacetone. It was also possible to demonstrate the formation of $\delta$-ALA from $\alpha$-ketoglutarate and glycine by the similar paper chromatographic technique without the aid of carriers and $\mathrm{C}^{14}$-labeled substrate. The data in Table I would indicate that the synthesis of $\delta$-ALA is greatly increased in AIA-induced porphyria rat.

When pyruvate and glycine were used as substrates, however, significant amounts of aminoketone were produced by mitochondria from either of normal and AIA rats and apparently no difference was observed in activity between normal and AIA rats. The aminoketonic product in pyruvate-glycine system was identified as aminoacetone and also shown to be almost free from $\delta$-ALA by the similar method as described for $\delta$-ALA. Aminoacetone formation in the pyruvate-glycine system appeared to require aerobiosis.

\section{2) Effect of various factors on $\delta$-ALA synthesis}

Since the reaction of $\delta$-ALA synthesis was shown to proceed anaerobically as well as aerobically, experiments in the followings were performed mainly anaerobically to minimize complexity by side reactions. Anaerobic synthesis of $\delta$-ALA was markedly increased by the addition of EDTA, while the reaction was inhibited by about $50 \%$ by potassium cyanide (Table II). The addition of ADP to the standard system reduced the yield of $\delta$-ALA approximately to one-half. When inorganic phosphate was omitted from the reaction mixture, the yield of $\delta$-ALA increased more than $60 \%$. Although not shown in the table, the increase in $\delta$-ALA synthesis was more pronounced when the glucose-hexokinase system was further added to the Pi-omitted system. These results could be explained by assuming that the splitting of succinyl-CoA into free succinate and $\mathrm{CoA}$ was accelerated by the addition of $\mathrm{ADP}$ and in turn reduced by omitting $\mathrm{Pi}$ through the mechanism of substrate-level phosphorylation, giving rise to decreased or increased supply of succinyl-CoA to the $\delta$-ALA synthesis system, respectively. Under aerobic conditions, on the other hand, the yield of $\delta$-ALA

TABLE II. Effect of KCN and EDTA on $\delta$-ALA Synthesis

\begin{tabular}{l|c|c}
\hline & $\begin{array}{c}\delta \text {-ALA formed } \\
(\mathrm{m} \mu \text { moles/mg. prot./hr. })\end{array}$ & $\begin{array}{c}\text { Relative activity } \\
(\%)\end{array}$ \\
\hline Standard system & 4.80 & 100 \\
plus KCN, $5 \times 10^{-4} M$ & 2.56 & 53 \\
minus EDTA & 1.42 & 30 \\
plus KCN, minus EDTA & 0.67 & 14
\end{tabular}

Standard system contained in final volume of $2.0 \mathrm{ml}$; ; phosphate buffer (pH 7.0) $100 \mu$ moles, $\mathrm{MgCl}_{2} 5 \mu$ moles, EDTA $25 \mu$ moles, glycine $100 \mu$ moles, $a$-ketoglutarate $10 \mu$ moles and $1.0 \mathrm{ml}$. of mitochondrial suspension $(45.7 \mathrm{mg}$. protein) from AIA rat. Reactions were run anaerobically for 60 minutes at $38^{\circ} \mathrm{C}$. 
Table III. Effect of Phosphorylation System on $\delta$-ALA Synthesis

\begin{tabular}{l|c|c} 
& $\begin{array}{r}\delta \text {-ALA formed } \\
(\mathrm{m} \mu \text { moles/mg. prot./hr. })\end{array}$ & $\begin{array}{c}\text { Relative activity } \\
(\%)\end{array}$ \\
\hline Expt. A (anaerobic) & & \\
Standard system & 3.76 & 100 \\
plus ADP $(10 \mu$ moles) & 1.57 & 42 \\
minus Pi & 6.20 & 164 \\
Expt. B (aerobic) & 2.70 & 100 \\
Standard system & 3.50 & 130 \\
plus ADP (10 $\mu$ moles) & 2.31 & 86
\end{tabular}

Standard system in Experiment A contained in final volume of $2.0 \mathrm{ml}$ : Tris. $\mathrm{HCl}$ buffer (pH 7.5) $100 \mu$ moles, phosphate buffer ( $\mathrm{pH}$. 7.0) $40 \mu$ moles, $\mathrm{MgCl}_{2} 5 \mu$ moles $(10$ $\mu$ moles when ADP was added), EDTA $25 \mu$ moles, glycine $100 \mu$ moles, $a$-ketoglutarate 10 $\mu$ moles, and $1.0 \mathrm{ml}$. of mitochondrial suspension (33.2 mg. protein) from AIA rat. In Experiment B, standard system contained in final volume of $2.3 \mathrm{ml}$. the same components as in Experiment $A$ except that $20 \mu$ moles of malonate were further added and $29 \mathrm{mg}$. protein of mitochondria were used. Incubated for 60 minutes at $38^{\circ} \mathrm{C}$.

TABLE IV. Effect of Phosphorylation System on Aminoacetone Synthesis

\begin{tabular}{c|c|c}
\hline & $\begin{array}{c}\text { Aminoacetone formed } \\
(\mathrm{m} \mu \text { moles/mg. prot./hr. })\end{array}$ & $\begin{array}{c}\text { Relative activity } \\
(\%)\end{array}$ \\
\hline Standard system & 2.60 & 100 \\
plus ADP $(10 \mu$ moles $)$ & 7.29 & 280
\end{tabular}

Standard System contained in final volume of $2.1 \mathrm{ml}$.: Tris-HCl buffer (pH 7.5) 100 $\mu$ moles, phosphate buffer (pH. 7.0) $40 \mu$ moles, $\mathrm{MgCl}_{2} 5 \mu$ moles (10 $\mu$ moles when ADP was added), glycine $200 \mu$ moles, pyruvate $200 \mu$ moles, and $1.0 \mathrm{ml}$. of mitochondrial suspension (31.2 mg. protein) from normal rat. Incubated aerobically for 60 minutes at $38^{\circ} \mathrm{C}$.

TABLE V. $\delta$-ALA Synthesis by Liver Mitochondria from Normal Rat

\begin{tabular}{l|c|c}
\hline & $\begin{array}{c}\delta \text {-ALA formed } \\
\text { (m } \mu \text { moles/mg. prot./hr. })\end{array}$ & $\begin{array}{c}\text { Relative activity } \\
(\%)\end{array}$ \\
\hline Standard system & 0.61 & 100 \\
plus malonate $(20 \mu$ moles $)$ & 1.00 & 164 \\
plus ADP (10 $\mu$ moles) & 1.05 & 172 \\
plus malonate, plus ADP & 1.46 & 240
\end{tabular}

Reaction conditions of standard system were similar to those of Table III. Expt. A, except that the final volume was $2.5 \mathrm{ml}$. and $1.0 \mathrm{ml}$. of mitochondrial suspension (33.3 mg. protein) from normal rat liver was used and incubated aerobically.

was highest when both ADP and inorganic phosphate were present, probably because of that the oxidation reaction from $\alpha$-ketoglutarate to succinyl-CoA was promoted by the coupling of terminal respiration with the oxidative phosphorylation. Similar relations were observed in aerobic synthesis of aminoacetone by 
liver mitochondria from normal rat. Namely, by the addition of ADP, aminoacetone synthesis was markedly stimulated (Table IV). Although the activity of normal rat liver mitochondria to synthesize $\delta$-ALA was very low in standard system, the yield of $\delta$-ALA could be increased significantly by employing suitable reaction conditions (Table V). When malonate and ADP were added under aerobic conditions, the synthesis of $\delta$-ALA was more than doubled.

\section{- 3) Stability of Enzyme Systems}

As shown in Table VI, when normal rat liver mitochondria were preserved at $0^{\circ} \mathrm{C}$ for 22 hours, yields of both $\delta$-ALA and aminoacetone were reduced by about $10 \%$. By keeping the mitochondria at $17^{\circ} \mathrm{C}$ for 4 hours, yields of both aminoketones were equally reduced by about $20 \%$. Similar results were obtained also with mitochondria from AIA rat. In general, the system of $\delta$-ALA synthesis appears to be a little less stable as compared to that of aminoacetone synthesis. Both activities in mitochondria however, were seriously reduced by one hour preincubation at $38^{\circ} \mathrm{C}$.

TABLE VI. Stability of Enzyme Systems

\begin{tabular}{|c|c|c|c|c|c|c|}
\hline & \multicolumn{2}{|c|}{ Preservation conditions } & \multicolumn{2}{|c|}{ \$.ALA formed } & \multicolumn{2}{|c|}{ Aminoacetone formed } \\
\hline & Time in hr. & $\begin{array}{c}\text { Tempt. } \\
\left({ }^{\circ} \mathrm{C}\right)\end{array}$ & $\begin{array}{c}(\mathrm{m} \mu \text { moles } / \mathrm{mg} . \\
\text { prot. } / \mathrm{hr} .)\end{array}$ & $(\%)$ & $\begin{array}{c}\text { (m } \mu \text { moles } / \mathrm{mg} . \\
\text { prot. } / \mathrm{hr} .)\end{array}$ & $(\%)$ \\
\hline \multicolumn{7}{|l|}{ Expt. A } \\
\hline \multirow[t]{4}{*}{ Normal rat } & 0 & 0 & 1.47 & 100 & 5.25 & 100 \\
\hline & 4 & 0 & 1.34 & 91 & 5.45 & 104 \\
\hline & 22 & 0 & 1.17 & 80 & 4.75 & 90 \\
\hline & 4 & 17 & 1.15 & 79 & 4.18 & 80 \\
\hline \multicolumn{7}{|l|}{ Expt. B } \\
\hline \multirow[t]{3}{*}{ AIA rat } & 0 & 0 & 8.32 & 100 & 4.90 & 100 \\
\hline & 2 & 0 & 7.51 & 90 & 5.07 & 103 \\
\hline & 8 & 0 & 7.80 & 93 & 5. 37 & 109 \\
\hline
\end{tabular}

8-ALA synthesis system was the same as the standard system in Table III, Expt. A, except that $10 \mu$ moles of ADP and $20 \mu$ moles of malonate were added in Expt. A of this table, and $10 \mu$ moles of ADP were added in Expt. B. System for aminoacetone synthesis was the same as the standard system in Table IV, except that $10 \mu$ moles of ATP were added. $1.0 \mathrm{ml}$. of mitochondrial suspension from normal rat contained $43.2 \mathrm{mg}$. protein, and that from AIA rat contained $38.4 \mathrm{mg}$. protein.

\section{4) Terminal Respiration of Liver Mitochondria}

Activities of succinate dehydrogenase, succinooxidase, $\alpha$-ketoglutarate dehydrogenase and NADH oxidase in liver mitochondrial preparations from normal and AIA-induced porphyrin rats are compared in Table VII. The data revealed that the terminal respiration systems were not affected in AIA rat. 
Table VII. Comparison of Respiratory Activities of Liver Mitochondria from Normal and AIA Rats

\begin{tabular}{|c|c|c|}
\hline Activities examined & Normal rat & AIA rat \\
\hline $\begin{array}{l}\text { Succinooxidase ( } \mu \mathrm{l} \text {. oxygen consumed/mg. } \\
\text { prot./hr.) }\end{array}$ & 52.7 & 53.5 \\
\hline $\begin{array}{l}\text { Succinate dehydrogenase (mumoles succinate } \\
\text { oxidized } / \mathrm{mg} \text {. prot./min.) }\end{array}$ & 19.7 & 17.3 \\
\hline $\begin{array}{l}\text { NADH oxidase (m } \mu \text { moles NADH oxidized } / \mathrm{mg} \text {. } \\
\text { prot. } / \mathrm{min} \text {.) }\end{array}$ & 13.9 & 13.2 \\
\hline $\begin{array}{l}\mathrm{C}^{14} \mathrm{O}_{2} \text { Liberation from succinate-1,4-C } \mathrm{C}^{14} \\
\text { (counts of } \mathrm{BaC}^{14} \mathrm{O}_{3} / \mathrm{min} . / \mathrm{mg} \text {. prot.) }\end{array}$ & 12.0 & 14.6 \\
\hline $\begin{array}{l}\text { Oxidation of } \alpha \text {-ketogultarate ( } \mu \mathrm{l} \text {. oxygen } \\
\text { consumed } / \mathrm{mg} \text {. prot./hr.) }\end{array}$ & 49.1 & 40.8 \\
\hline
\end{tabular}

Activities of succinooxidase and $\alpha$-ketoglutarate oxidation were assayed manometrically in $3.0 \mathrm{ml}$. system at $30^{\circ} \mathrm{C}$, using $40 \mu$ moles of succinate or $40 \mu$ moles of $\alpha$-ketoglut arate, respectively. $a$-Ketoglutarate system contained also $10 \mu$ moles each of ADP and $\mathrm{MgCl}_{2}$. Succinate dehydrogenase activity was assayed photometrically by following the reduction of 2,6-dichlorophenol-indopenol at $600 \mathrm{~m} \mu$. NADH oxidaseactivity was measured by the decrease in optical density at $340 \mathrm{~m} \mu$. Radioisotope experiments were performed using $50 \mu$ moles of $0.002 \mathrm{mc} / \mathrm{mmole}$ succinate-1, 4- $\mathrm{C}^{14}$ as he substrate. Appropriate reaction conditions of each assay system were determined by preliminary experiments.

\section{5) Metabolic Decomposition of $\delta-A L A$}

Liver mitochondria from normal and AIA rats were incubated respectively with $\delta$-ALA-5- $\mathrm{C}^{14}$ for 60 minutes at $38^{\circ} \mathrm{C}$ under aerobic conditions, and radioactivities of $\mathrm{CO}_{2}$ evolved were compared. In either cases, the radioactivities of $\mathrm{CO}_{2}$ evolved were very small: 1.5 c.p.m./mg. protein in normal rat system and 1.14 c.p.m./mg. protein in AIA rat system. Also PBG formation from $\delta$-ALA by either of these two mitochondrial preparations was very small. These results clearly indicate that the apparent increase in $\delta$-ALA synthesis as observed for AIA rat can not be due to the decreased catabolism of $\delta$-ALA in AIA rat.

\section{DISCUSSION}

Our experimental results are consistent with the veiw that the primary feature of chemical porphyria induced by allylisopropylacetamide might be the overproduction of $\delta$-ALA in liver mitochondria. Various probable bases can be assumed for this overproduction: a) increase in $\delta$-ALA synthetase content in liver mitochondria, b) increased activity of succinyl-CoA supplying system, and c) suppression of succinyl-CoA decomposing system. With respect to the possibility a), it is noteworthy that there was no significant difference in activity of synthesizing aminoacetone between liver mitochondrial preparations from normal and AIA treated rats when we consider that $\delta$-ALA synthetase preparations from photosynthetic bacteria ${ }^{13)}$ and from chicken reticulocytes ${ }^{11}$ ) as well have been shown 
to catalyse also the synthesis of aminoacetone, though at lower rates. Recently the synthesis of aminoacetone by liver mitochondria has been reported by Urata and Granick. ${ }^{14)}$ It may be possible however, that the syntheses of $\delta$ ALA and aminoacetone in rat liver mitochondria are catalyzed by independent enzymes. Stability tests of the two enzymic activities were not helpful in solving the problem. Even if the independent enzymes were functioning in rat liver mitochondria, a possibility cannot be overlooked that the increased synthesis of $\delta$-ALA in experimental porphyria may be due, at least in part, to some change in succinyl-CoA supplying system. In fact, the yield of $\delta$-ALA synthesized by liver mitochondria from AIA rat varied significantly according to the reaction conditions as shown in Table III, and also $\delta$-ALA synthesis by normal rat liver mitochondria could considerably be increased by employing suitable reaction conditions as shown in Table V. It should be taken into considerations that the values of $\delta$-ALA synthesis as measured may not always reflect the real activity of $\delta$-ALA synthetase in mitochondrial preparations used. It remains to be solved what alteration, if any, in succinyl-CoA supplying system may be responsible to the increased $\delta$-ALA synthesis in AIA-induced porphyria. Recently, Labbe ${ }^{5}$ ) reported that heme and fatty acid syntheses in liver were both greater in porphyric animals and suggested that malonyl CoA could partially block the conversion of succinyl-CoA to succinate, thus resulting in succinyl-CoA being shunted in greater amount into the heme pathway. Also it is interesting to note that the system of $\alpha$-ketoglutarate oxidation in liver mitochondria has been shown to have some compartmentalization with respect to oxidative phosphorylation. ${ }^{15}$

\section{SUMMARY}

A chemical porphyria was induced in rat by feeding allylisopropylacetamide (AIA) and activities in liver mitochondria to synthesize aminoketones were studied.

It was shown that the activity to synthesize $\delta$-aminolevulinic acid ( $\delta$-ALA) was high in liver mitochondria from AIA-induced porphyria rat, while it was very low in normal rat. In contrast, both mitochondria from normal and AIAtreated rats produced large amounts of aminoacetone and no activity difference was noticed between normal and porphyria rats. The $\delta$-ALA synthesizing activity of liver mitochondria varied significantly according to the reaction conditions employed; particularly the yield of $\delta$-ALA was increased by omitting ADP or Pi from the reaction system under anaerobic conditions.

Activities of terminal respiration systems in AIA-treated rat were found to be unaffected. $\delta$-ALA was scarcely catabolyzed by liver mitochondrial preparations from either of normal and porphyria rats.

Significance of succinyl-CoA supplying system in controling the activity of 
$\delta$-ALA synthesis was discussed in relation to chemical porphyria.

\section{Acknowledgment}

The authors wish to acknowledge Prof. T. Ishibashi of the Department of Neuropsychiatry of this University for his providing T. Miyakoshi, one of the authors, with an opportunity to carry out this work and for his interest. Also thanks are due to Dr. M. Yokoyama in this Department for his help in identifying the aminoketones produced.

\section{References}

1) Schmid, R., Figen, J.F. \& Schwarz, S., J. Biol. Chem., 1955, 217, 263.

2) Talman, E.L., Case, J.D. \& Nevé, R.A., J. Biol. Chem., 1955, 212, 663.

3) Schwarz, S., Fed. Proc., 1955, 14, 717.

4) Marchante, A., Wajchenberg, B.L. \& Schwarz, S., Proc. Soc. Expt. Biol. Med., $1957,95,221$.

5) Labbe, R.F., Hanawa, Y. \& Lottesfeldt, F.I., Arch. Biochem. Biophys., 1961, 92, 373.

6) Rimington, C., Acta Med. Scand., 1952, 143, 161.

7) Granick, S., 'Chemical Pathways of Metabolism' (edited by D.M. Greenberg), 1954, Vol. II, p. 287.

8) Sano, S., Acta Haematol. Japonica, 1958, 21, 337.

9) Urata, G. \& Granick, S., cited in 'Metabolic Pathways' (edited by D.M. Greenberg), 1961, Vol. II, p. 606.

10) Schneider, W.C. \& Hogeboom, G.H., J. Biol. Chem., 1950, 183, 123.

11) Gibson, K.D., Laver, W.G. \& Neuberger, A., Biochem. J., 1958, 70, 71.

12) Mauzerall, D. \& Granick, S., J. Biol. Chem., 1956, 219, 435.

13) Kikuchi, G., Kumar, A. \& Shemin, D., Fed. Proc., 1959, 18, 259.

14) Urata, G. \& Granick, S.. Biochem. Biophys. Res. Comm., 1961, 4, 96.

15) Azzone, G.F. \& Ernster, L., J. Biol. Chem., 1961, 236, 1501 